\title{
Role of Microorganisms for the Sustainable Use of Soil Pollution Abutment in Agriculture Lands
}

\author{
Narayan Prasad Verma*, Dhannidevi, Bhisham Sinha and Anjulata Suman Patry \\ Department of Agricultural Microbiology, College of Agriculture, IGKV, \\ Raipur (C.G.) - 492006, India \\ *Corresponding author
}

\author{
A B S T R A C T
}

Keywords

Role of

microorganisms,

Sustainable use,

Soil pollution.

Article Info

Accepted:

04 September 2017

Available Online:

10 November 2017
The microorganisms have been introduced to describe the process of using biological agents to remove toxic contamination from agricultural lands. Microorganisms are the most effective management tool to manage the polluted environment and recover contaminated soil. The hazardous wastes generated from the chemical processes/operations are being treated using biological methods by meet the prescribed standard as per the Environmental Protection Act, 1986. The soil pollution treated by the in situ isolated microbes strain, before isolated metagenomic technology into the environment. In spite of the present treatment technology, the organic pollutants are found persisting in the soil-water environment above their acceptable level. Hence, beneficial microorganism is an innovative technology that has the potential to alleviate the toxic contamination.

\section{Introduction}

Soil contamination or soil pollution as part of land degradation is caused by the presence of xenobiotic (human-made) chemicals or other alteration in the natural soil environment. It is typically caused by industrial activity, agricultural chemicals, or improper disposal of waste. The most common chemicals involved are petroleum hydrocarbons, polynuclear aromatic hydrocarbons [such as naphthalene and benzo (a) pyrene], solvents, pesticides, lead, and other heavy metals. Contamination is correlated with the degree of industrialization and intensity of chemical usage. The concern over soil contamination stems primarily from health risks, from direct contact with the contaminated soil, vapors from the contaminants, and from secondary contamination of water supplies within and underlying the soil (George et al.,2016).

Soil pollution is caused by acid rains and particles loaded with heavy metals, falling at the same time with the acid rains or blown from the sterile stockpiles resulted from floating and smelting processes (Lacatusu et al., 1999). Soil contamination by heavy metals is a significant problem, which leads to changes of soil characteristics and limits productive and environmental functions. Polluted soils are no longer appropriate for 
agricultural production, because they are unable to produce healthy food. Assessment of soil pollution by heavy metals in Slovakia is determined by limit values of risk elements, which were set by law (Act No. 220/2004).

Agricultural pollution refers to biotic and abiotic byproducts of farming practices that result in contamination or degradation of the environment and surrounding ecosystems, and/or cause injury to humans and their economic interests. The pollution may come from a variety of sources, ranging from point source pollution (from a single discharge point) to more diffuse, landscape-level causes, also known as non-point source pollution. Management practices play a crucial role in the amount and impact of these pollutants. Management techniques range from animal management and housing to the spread of pesticides and fertilizers in global agricultural practices (Gullan and Cranston, 2010).

Pesticides and herbicides is a substance or mixture of substances used to kill a pest. A pesticide may be a chemical substance, biological agent (such as a virus or bacteria), antimicrobial, disinfectant or device used against any pest. Pests include insects, plant pathogens, weeds, mollusks, birds, mammals, fish, nematodes (roundworms) and microbes that compete with humans for food, destroy property, spread or are a vector for disease or cause a nuisance. Although there are benefits to the use of pesticides, there are also drawbacks, such as potential toxicity to humans and other organisms.

\section{Causes of soil pollution}

The European Commission has proposed the following definition of 'contaminated site': a site where there is a confirmed presence, caused by human activities, of hazardous substances to such a degree that they pose a significant risk to human health or the environment, taking into account land use (Commission Proposal COM (2006).

\section{Types of contamination}

As a starting point for looking at the types of contaminant that could be present in soils and affect human health, it is worthwhile to consider the chemicals that offer the greatest threat to human health first. The grid below gives details on the chemicals of major public health concern identified by the WHO.

\section{Heavy metals}

'Heavy metals' is a widely-used term for elements with metallic properties - it is not, in fact, a scientifically accurate description, since the definition of 'heavy' is not fixed, and some so-called heavy metals, such as arsenic and antimony, are semi-metals or metalloids. Another description often used interchangeably with heavy metals is 'trace elements'.

These elements occur naturally in rocks and in variable amounts in soils, depending on their location and the rocks that have broken down to make the soil's components. The group 'heavy metals 'for the purpose of discussing health risks or impacts generally includes:

Arsenic (As)

Lead $(\mathrm{Pb})$

Cadmium (Cd)

Chromium (Cr)

(Although only the form $\mathrm{Cr}(\mathrm{VI})$ is toxic)

Copper $(\mathrm{Cu})$

Mercury $(\mathrm{Hg})$

Nickel (Ni)

Zinc (Zn) 


\section{Asbestos}

Asbestos contamination in the soil is of concern in a number of locations, because it can be released to the air by the wind or by human disturbance. Asbestos has long-term health consequences if it is inhaled, with increased mortality from lung cancer and mesothelioma the most extreme outcomes.

\section{Dioxins and dioxin-like chemicals}

Dioxins are a group of chemically-related compounds that are persistent organic pollutants (POPs). Highly toxic, dioxins accumulate up the food chain, with the highest levels found in animals at the top of the food chain (an effect known as 'biomagnifications').

More than $90 \%$ of human exposure to dioxins is through food, mainly meat and dairy products, fish and shellfish.

\section{Organic pollutants, including hazardous pesticides}

Organic (carbon-based) pollutants include pesticides. Those that were once released into air or water will end up in soils, with the exception of those that are deposited at the bottom of oceans. Among organic pollutants some are referred to as 'POPs,' or persistent organic pollutants, which do not break down quickly in the environment.

Types of organic pollutants found in soil include

Polychlorinated biphenyls (PCBs)

Polybrominated biphenyls

Polychlorinated dibenzofurans (PCDFs)

Polycyclic aromatic hydrocarbons (PAHs)
Organophosphorus and carbamate insecticides (pesticides)

Herbicides

Organic fuels (gasoline, diesel)

Pharmaceuticals and their metabolites

The effects of the soil and organisms within it upon organic pollutants are unknown. The data that do exist tend to be on short-term, high level exposure of these chemicals, which is less relevant to the potential low-level, long term health impacts from living near to contaminated soil (Burgess, 2013).

\section{Sources of heavy metals in contaminated soils}

\section{Direct sources}

The prime direct source of xenobiotics is wastewater and solid residual releases from the industries like chemical and pharma, plastics, paper and pulp mills, textile mills, agricultural (enhancement products like pesticides, herbicides etc.). Some of the common residual compounds in the wastewater and other effluents are Phenol, hydrocarbons, different dyes, paint effluents, Pesticides and Insecticides etc.

\section{Indirect sources}

Indirect sources of xenobiotics include NSAIDs, pharmaceutical compounds, pesticide residues etc. Pharmaceutically active compounds, being an indirect source of xenobiotics are discharged directly by manufacturers of the pharmaceuticals or effluents from hospitals which have performed their biologically intended effect and are passed onto the environment in either their complete or a fragmented state. These mainly include hormones, anesthetics and 
antibiotics which bioaccumulation in an organism and passed on the other through the common food chain.

Heavy metals occur naturally in the soil environment from the pedogenetic processes of weathering of parent materials at levels that are regarded as trace $(<1000 \mathrm{mg} \mathrm{kg}-1)$ and rarely toxic (Kabata-Pendias and Pendias, 2001, Pierzynski, et al., 2000]. Due to the disturbance and acceleration of nature's slowly occurring geochemical cycle of metals by man, most soils of rural and urban environments may accumulate one or more of the heavy metals above defined background values high enough to cause risks to human health, plants, animals, ecosystems, or other media (D'Amore, et al., 2005).

\section{Fertilizers}

Agriculture was the first major human influence on the soil (Scragg, 2006). To grow and complete the lifecycle, plants must acquire not only macronutrients $(\mathrm{N}, \mathrm{P}, \mathrm{K}, \mathrm{S}$, $\mathrm{Ca}$, and $\mathrm{Mg}$ ), but also essential micronutrients. Some soils are deficient in the heavy metals (such as $\mathrm{Co}, \mathrm{Cu}, \mathrm{Fe}, \mathrm{Mn}, \mathrm{Mo}$, $\mathrm{Ni}$, and $\mathrm{Zn}$ ) that are essential for healthy plant growth (Lasat, 2000).

Fertilizer industry is considered to be source of natural radionuclide's and heavy metals as a potential source. It contains a large majority of the heavy metals like $\mathrm{Hg}, \mathrm{Cd}, \mathrm{As}, \mathrm{Pb}, \mathrm{Cu}$, $\mathrm{Ni}$, and $\mathrm{Cu}$; natural radionuclide like 238U, 232Th, and 210Po (FAO, March, 2009). However, in recent years, fertilizer consumption increased exponentially throughout the world, causes serious environmental problems. Fertilization may affect the accumulation of heavy metals in soil and plant system. Plants absorb the fertilizers through the soil; they can enter the food chain. Thus, fertilization leads to water, soil and air pollution.

\section{Pesticides}

Although some persistent organ chlorine pesticides have been banned from agricultural and public health use during the past few decades, high concentrations of DDT and its metabolites have been found in soil, water, and sediment samples (Shen et al., 2005; Miersma et al., 2003; Yan ez et al., 2002; Bould, 1994). Furthermore, other insecticides, such as endosulfan and lindane, are currently in use throughout the world (EPA, 2002) and their presence in air, water, and soil is a problem of great concern. Reducing their levels in the environment has therefore become an important goal.

Several common pesticides used fairly extensively in agriculture and horticulture in the past contained substantial concentrations of metals. For instance in the recent past, about $10 \%$ of the chemicals have approved for use as insecticides and fungicides in UK were based on compounds which contain $\mathrm{Cu}$, $\mathrm{Hg}, \mathrm{Mn}, \mathrm{Pb}$, or $\mathrm{Zn}$. Examples of such pesticides are copper-containing fungicidal sprays such as Bordeaux mixture (copper sulphate) and copper oxychloride (Jones and Jarvis, 1981).

\section{Herbicide}

Three different herbicides were considered in our research: terbuthylazine, simazine and linuron. They were selected because they are common soil and groundwater contaminants (Di Corcia et al., 1999; Barra Caracciolo et al., 2005b and 2005d, Guzzella et al., 2006a and 2006b). The phenylurea herbicides, such as linuron, are an important group of pesticides used predominantly in either preor post-emergence treatment of cotton, fruit, cereal or other agricultural crops. The degradation data reported are quite variable; with DT50values in the range of 38-135 days in laboratory studies and 13-82 days in field 
ones (Caux et al., 1998; Rodríguez-Cruz et al., 2001; Rasmussen et al., 2005).

\section{Bioslids and manures}

The application of numerous biosolids (e.g., livestock manures, composts, and municipal sewage sludge) to land inadvertently leads to the accumulation of heavy metals such as As, $\mathrm{Cd}, \mathrm{Cr}, \mathrm{Cu}, \mathrm{Pb}, \mathrm{Hg}, \mathrm{Ni}, \mathrm{Se}, \mathrm{Mo}, \mathrm{Zn}, \mathrm{Tl}, \mathrm{Sb}$, and so forth, in the soil.

Heavy metals most commonly found in biosolids are $\mathrm{Pb}, \mathrm{Ni}, \mathrm{Cd}, \mathrm{Cr}, \mathrm{Cu}$, and $\mathrm{Zn}$, and the metal concentrations are governed by the nature and the intensity of the industrial activity, as well as the type of process employed during the biosolids treatment (Basta, 2005).

Under certain conditions, metals added to soils in applications of biosolids can be leached downwards through the soil profile and can have the potential to contaminate groundwater (Mattigod and Page, 1983). Recent studies on some New Zealand soils treated with biosolids have shown increased concentrations of $\mathrm{Cd}, \mathrm{Ni}$, and $\mathrm{Zn}$ in drainage leachates (McLaren et al., 2005; Keller et al., 2002).

\section{Wastewater}

The application of municipal and industrial wastewater and related effluents to land dates back 400 years and now is a common practice in many parts of the world [Reed, et al., 1995]. Worldwide, it is estimated that 20 million hectares of arable land are irrigated with waste water.

In several Asian and African cities, studies suggest that agriculture based on wastewater irrigation accounts for 50 percent of the vegetable supply to urban areas (Bjuhr, 2007).
Metal mining and milling processes and industrial wastes

Mining and milling of metal ores coupled with industries have bequeathed many countries, the legacy of wide distribution of metal contaminants in soil.

During mining, tailings (heavier and larger particles settled at the bottom of the flotation cell during mining) are directly discharged into natural depressions, including onsite wetlands resulting in elevated concentrations (DeVolder, et al., 2003).

Other materials are generated by a variety of industries such as textile, tanning, petrochemicals from accidental oil spills or utilization of petroleum-based products, pesticides, and pharmaceutical facilities and are highly variable in composition. Although some are disposed of on land, few have benefits to agriculture or forestry.

In addition, many are potentially hazardous because of their contents of heavy metals $(\mathrm{Cr}$, $\mathrm{Pb}$, and $\mathrm{Zn}$ ) or toxic organic compounds and are seldom, if ever, applied to land. Others are very low in plant nutrients or have no soil conditioning properties (Sumner, 2000).

\section{Air-borne sources}

Airborne sources of metals include stack or duct emissions of air, gas, or vapor streams, and fugitive emissions such as dust from storage areas or waste piles. Metals from airborne sources are generally released as particulates contained in the gas stream. Some metals such as $\mathrm{As}, \mathrm{Cd}$, and $\mathrm{Pb}$ can also volatilize during high-temperature processing. These metals will convert to oxides and condense as fine particulates unless a reducing atmosphere is maintained (Smith $e t$ al., 1995). 


\section{Ten chemicals of major public health concern}

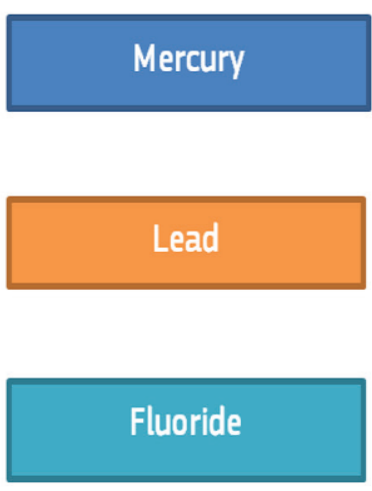

Dioxin

\section{Hazardous pesticides}

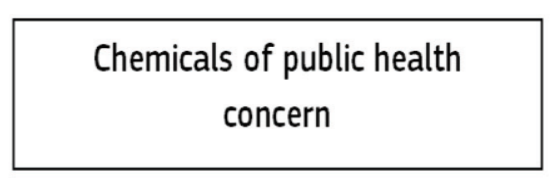

Cadmium

\section{Air pollution}

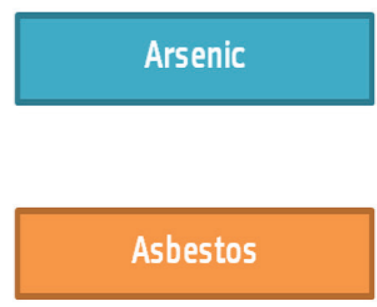

Benzene

Source: adapted from WHO

\section{Sources of heavy metals in contaminated soils}
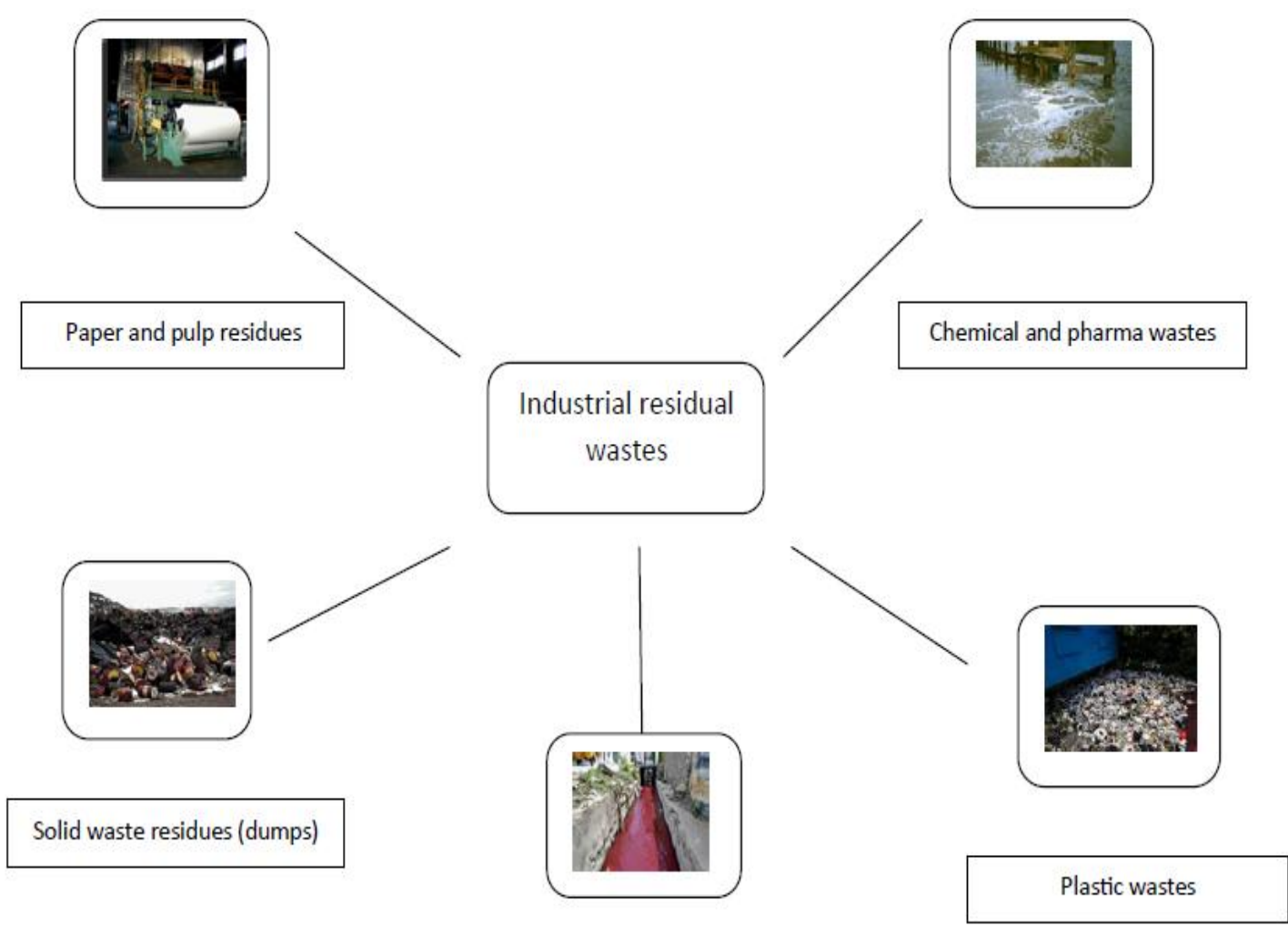

Paint and dye effluents 
Biodegradation

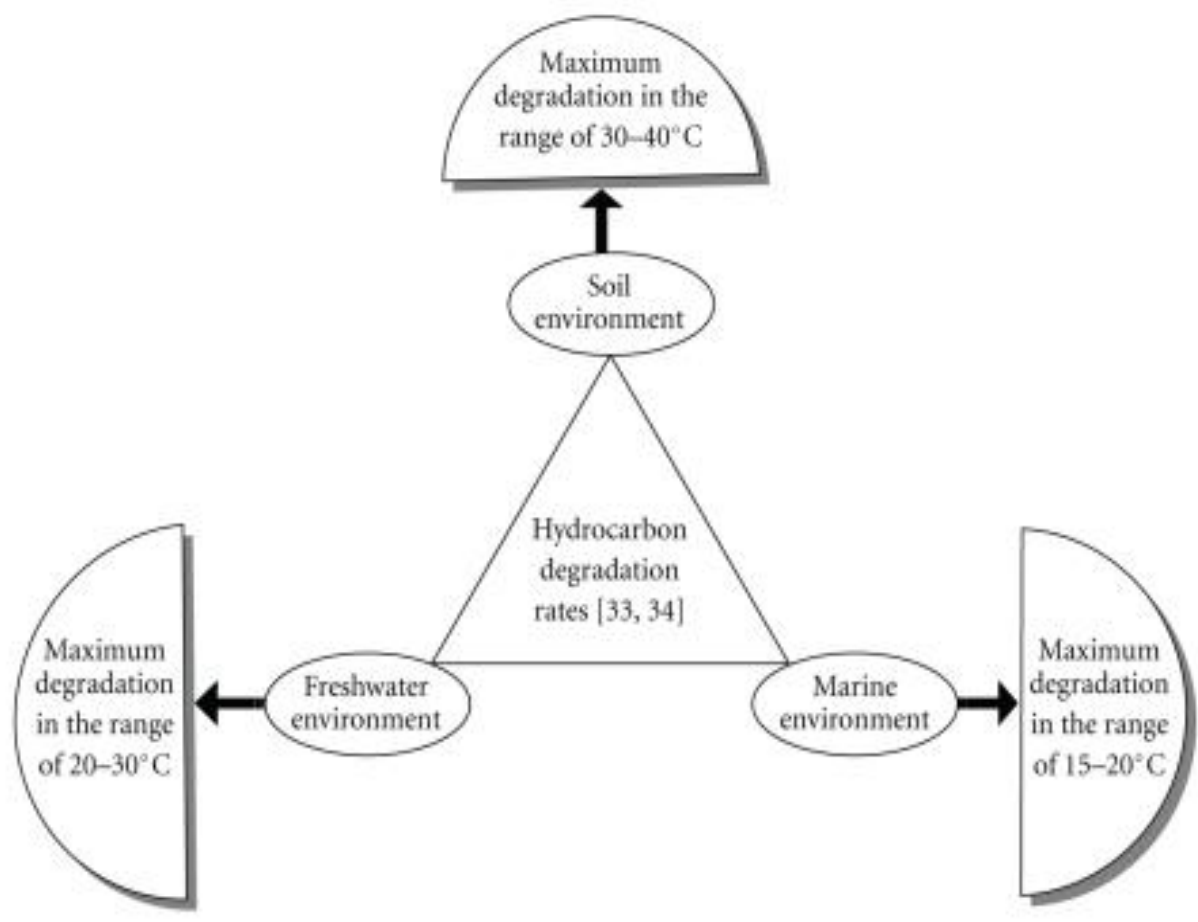

Anaerobic biodegradation

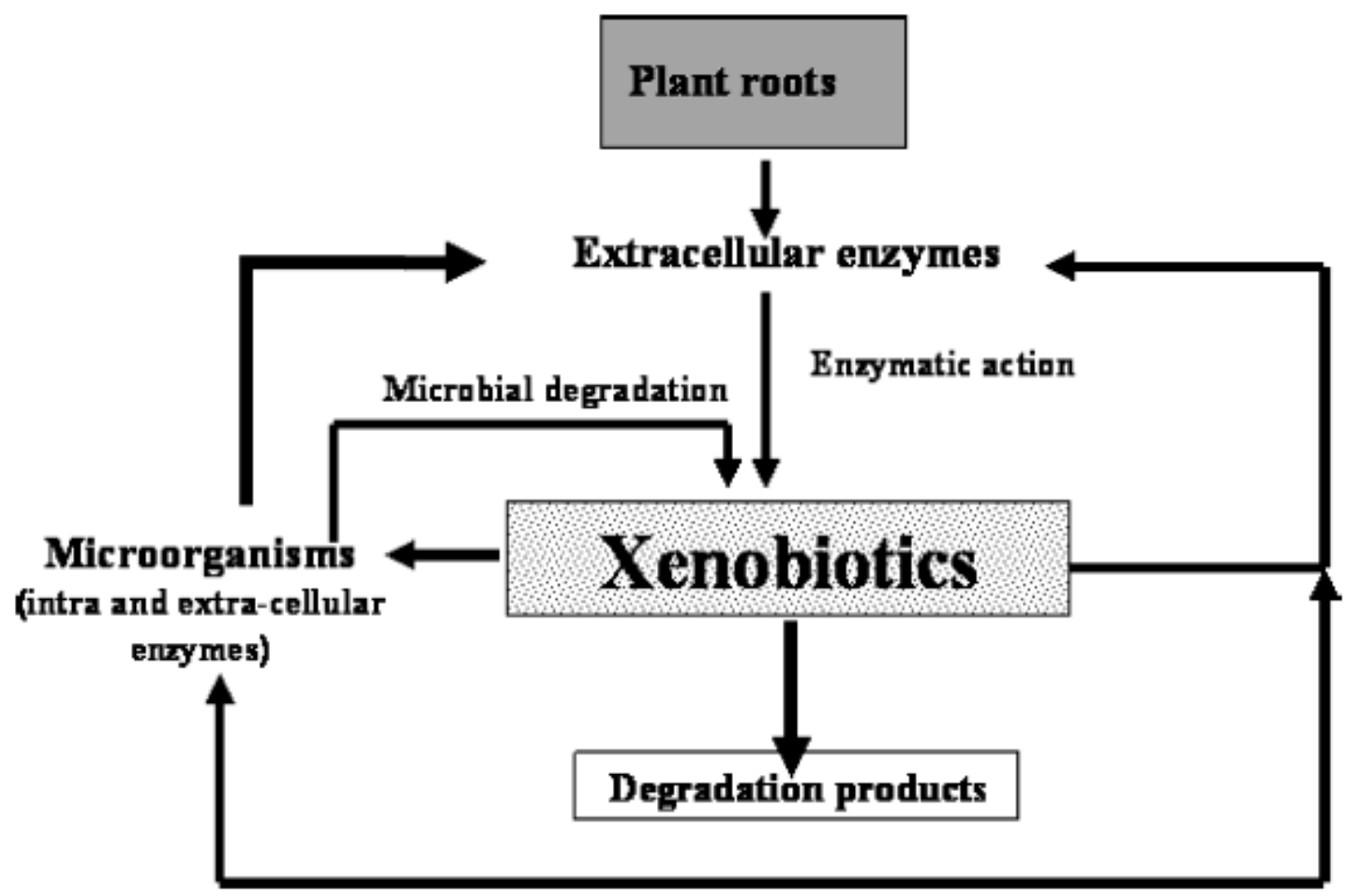




\section{Bioremediation}

\begin{tabular}{|c|c|c|c|c|}
\hline Technology & Examples & Benefits & Limitations & Factors to consider \\
\hline In situ & $\begin{array}{l}\text { In situ bioremediation } \\
\text { Biosparging } \\
\text { Bioventing } \\
\text { Bioaugmentation }\end{array}$ & $\begin{array}{l}\text { Most cost efficient } \\
\text { Noninvasive } \\
\text { Relatively passive } \\
\text { Natural attenuation } \\
\text { processes } \\
\text { Treats soil and water }\end{array}$ & $\begin{array}{l}\text { Environmental } \\
\text { constraints } \\
\text { Extended treatment } \\
\text { time } \\
\text { Monitoring difficulties }\end{array}$ & $\begin{array}{l}\text { Biodegradative abilities of } \\
\text { indigenous microorganisms } \\
\text { Presence of metals and } \\
\text { other inorganics } \\
\text { Environmental parameters } \\
\text { Biodegradability of pollutants } \\
\text { Chemical solubility } \\
\text { Geological factors } \\
\text { Distribution of pollutants }\end{array}$ \\
\hline Ex situ & $\begin{array}{l}\text { Landfarming } \\
\text { Composting } \\
\text { Biopiles }\end{array}$ & $\begin{array}{l}\text { Cost efficient } \\
\text { Low cost } \\
\text { Can be done on site }\end{array}$ & $\begin{array}{l}\text { Space requirements } \\
\text { Extended treatment time } \\
\text { Need to control abiotic } \\
\text { loss } \\
\text { Mass transfer problem } \\
\text { Bioavailability limitation }\end{array}$ & See above \\
\hline Bioreactors & $\begin{array}{l}\text { Slurry reactors } \\
\text { Aqueous reactors }\end{array}$ & $\begin{array}{l}\text { Rapid degradation kinetic } \\
\text { Optimized environmental } \\
\text { parameters } \\
\text { Enhances mass transfer } \\
\text { Effective use of inoculants } \\
\text { and surfactants }\end{array}$ & $\begin{array}{l}\text { Soil requires excavation } \\
\text { Relatively high cost } \\
\text { capital } \\
\text { Relatively high operating } \\
\text { cost }\end{array}$ & $\begin{array}{l}\text { See above } \\
\text { Bioaugmentation } \\
\text { Toxicity of amendments } \\
\text { Toxic concentrations of } \\
\text { contaminants }\end{array}$ \\
\hline
\end{tabular}

Degradable Organic Hazardous Wastes and the Associated Microorganisms

Hazardous Organic Compounds Microorganisms Involved in Degradation

Phenylmercuric acetate

Raw rubber, hevea latex

Detergents

PCBS

Malathion

Endrin

Lindane

DDT

Dieldrin
Pseudomonas, Arthrobacter, Citrobacter, Vibrio

Actinomycetes

Nocardia, Pseudomonas

Notidentified

Trichoderma, Pseudomonas

Arthrobacter, Bacillus

Closteridium

Escherichia, Hydrogenomonas, Saccharomyces

Mucor

Sources: Various Publications of UNEP, WWF and WHO (1992-2002) 
Table.1 Microorganisms having biodegradation potential for xenobiotics

\begin{tabular}{|l|l|l|}
\hline Microorganisms & Toxic Chemicals & Reference \\
\hline Pseudomonas spp. & $\begin{array}{l}\text { Benzene, anthracene, hydrocarbons, } \\
\text { PCBs }\end{array}$ & Cybulskiet al, 2003 \\
\hline Alcaligenes spp. & $\begin{array}{l}\text { Halogenated hydrocarbons, linear } \\
\text { alkylbenzene sulfonates, polycyclic } \\
\text { aromatics, PCBs }\end{array}$ & Kapleyet al., 1999 \\
\hline Arthrobacter spp. & $\begin{array}{l}\text { Benzene,hydrocarbons,pentachlorop } \\
\text { henol, phenoxyacetate, polycyclic } \\
\text { aromatic, Aromatics, long chain alkanes, } \\
\text { phenol, Cresol }\end{array}$ & Jogdand, 1995 \\
\hline Bacillus spp. & $\begin{array}{l}\text { Halogenated hydrocarbons, } \\
\text { phenoxyacetates }\end{array}$ & Cybulskiet al.,2003 \\
\hline Corynebacterium spp. & Aromatics & Jogdand, 1995 \\
\hline Flavobacterium spp. & $\begin{array}{l}\text { Aromatics } \\
\text { Naphthalene, biphenyl }\end{array}$ & Jogdand, 1995 \\
\hline Azotobacter spp. & $\begin{array}{l}\text { Aromatics, branched hydrocarbons } \\
\text { benzene,cycloparaffins }\end{array}$ & $\begin{array}{l}\text { Jogdand, 1995 } \\
\text { DeanRosset al.,2002 }\end{array}$ \\
\hline Rhodococcus spp. & $\begin{array}{l}\text { Hydrocarbons } \\
\text { Aromatics }\end{array}$ & DeanRosset al.,2002 \\
\hline Mycobacterium spp. & $\begin{array}{l}\text { Aromatics } \\
\text { Hydrocarbons, polycyclic hydrocarbons }\end{array}$ & Park et al., 1998 \\
\hline Nocardia spp. & $\begin{array}{l}\text { Phenoxyacetate, halogenated } \\
\text { hydrocarbon diazinon }\end{array}$ & Jogdand, 1995 \\
\hline Methosinus sp. & PCBs, formaldehyde & Ijah, 1998 \\
\hline Methanogens & PCBs, polycyclic aromatics, biphenyl & Jogdand, 1995 \\
\hline
\end{tabular}

Genetic engineering for biodegradation of contaminants

\begin{tabular}{||l|l|l|l||}
\hline Microorganisms & Modification & Contaminants & Reference \\
\hline \hline Pseudomonas. putida & pathway & 4-ethylbenzoate & Ramos et al., \\
\hline \hline P. putida KT2442 & pathway & toluene/benzoate & $\begin{array}{l}\text { Panke and } \\
\text { Sanchezromero }\end{array}$ \\
\hline \hline Pseudomonas sp.FRI & pathway & chloro-, methylbenzoates & Rojo et al., \\
\hline \hline Comamonas. testosteroni VP44 & substrate specificity & o-, p-monochlorobiphenyls & Hrywna et al., \\
\hline Pseudomonas sp. LB400 & substrate specificity & PCB & $\begin{array}{l}\text { Erickson and } \\
\text { Mondello }\end{array}$ \\
\hline \hline P. pseudoalcaligenes KF707-D2 & substrate specificity & TCE, toluene, benzene & Suyama et al., \\
\hline
\end{tabular}


Indigenous microorganisms in remediation of contaminated soils

Degradation of organic compound by indigenous microbes without any artificial enhancement is termed as an "intrinsic bioremediation" and this is one of the best remedial actions for soil contamination. Generally, biodegradation means mineralization of organic constituents to the soluble inorganic compounds or to transform organic constituents to other soluble organic compounds. In the process of biodegradation of an organic compound, a wide variety of microbial enzymes are involved in transforming both artificial and natural hydrocarbons into intermediate compounds which may be less or equally hazardous than the parental compounds (Baduru Lakshman Kumar and Sai Gopal, 2015).

Remediation of environment niches such as soil, sediments and water amended with heavy metals can be achieved through biologically encoded changes in the oxidation state. Bioremediation is the microbe-mediated process for clearance or immobilization of the contaminants, including all possible toxins like hydrocarbons, agrochemicals and other organic toxicants. But for inorganic toxic compounds such as heavy metals, microbes are unable to simplify them into harmless compounds, and they should be used according to their specialization for the type of contaminants. Thus the bioremediation strategy for heavy metals depends on the active metabolizing capabilities of microorganisms (Ahemad, 2014) (Table 1).

\section{Bioremediation}

Bioremediation is not only a process of removing the pollutant from the environment but also it an eco-friendly and more effective process (Singh and Tripathi, 2007). The pollutants can be removes or detoxify from the soil and water by the use of microorganism, known as bioremediation (Talley, 2005). The purpose of bioremediation is to make environment free from pollution with help of environmental friendly microbes. Bioremediation broadly can be divided in two category i.e. In-situ bioremediation and exsitu bioremediation.

Bioremediation is a microorganism mediated transformation or degradation of contaminants into nonhazardous or lesshazardous substances. The employability of various organisms like bacteria, fungi, algae, and plants for efficient bioremediation of pollutants has been reported (Vidali, 2001; Leung, 2004). The involvement of plants in the bioremediation of pollutants is called as phytoremediation. The process of phytoremediation is an emerging green technology that facilitates the removal or degradation of the toxic chemicals in soils, sediments, groundwater, surface water, and air (RTDF). Genetically, engineered plants are also in use. For instance arsenic is phytoremediated by genetically modified plants such as Arabidopsis thaliana which expresses two bacterial genes. One of these genes allows the plant to modify arsenate into arsenite and the second one binds the modified arsenite and stores it in the vacuoles (Leung, 2004).

Microbiological cultures, enzyme additives, or nutrient additives that significantly increase the rate of biodegradation to mitigate the effects of the discharge were defied as bioremediation agents by U.S.EPA (Nichols, 2001). Bioremediation agents are classified as bioaugmentation agents and biostimulation agents based on the two main approaches to oil spill bioremediation. Numerous bioremediation products have been proposed and promoted by their vendors, especially 
during early 1990s, when bioremediation was popularized as "the ultimate solution" to oil spills (Hoff, 1993).

\section{Biodegradation}

Biodegradation of petroleum hydrocarbon compounds toluene and o-xylene (BTX) by Pseudomonas putida strain MHF 7109 Pseudomonas putida MHF 7109 has been isolated and identified from cow dung microbial consortium for biodegradation of selected petroleum hydrocarbon compounds benzene, toluene, and o-xylene (BTX). Each compound was applied separately at concentrations of $50,100,250$, and $500 \mathrm{mgL}-1$ in minimal salt medium to evaluate degradation activity of the identified microbial strain. The mass spectrometry analysis identified the intermediates as catechol, 2-hydroxymuconic semialdehyde, 3methylcatechol, cis-2- hydroxypenta-2,4dienoate, 2-methylbenzyl alcohol, and 1,2dihydroxy-6- methylcyclohexa- 3,5dienecarboxylate, for BTX, respectively. P. putida MHF 7109 has been found to have high potential for biodegradation of volatile petroleum hydrocarbons (Singh and Fulekar, 2010).

Microorganisms provide a potential wealth in biodegradation. The ability of these organisms to reduce the concentration of xenobiotics is directly linked to their longterm adaptation to environments where these compounds exist. Moreover, genetic engineering may be used to enhance the performance of such microorganisms that have the preferred properties, essential for biodegradation (Schroll et al., 2004).

The contamination of soils and groundwater with petroleum compounds is among the most prevalent problems in environments worldwide (Alquati, 2005). In situ biodegradation is one of the primary mechanisms by which petroleum and other hydrocarbons are eliminated from the environment. Hydrocarbon-degrading bacteria are widely distributed in marine, freshwater, soil habitats and their use in bioremediation of hydrocarbon-contaminated soils, which exploits their ability to degrade and/or detoxify organic contaminants, has been established as an efficient, economical, versatile and environmentally sound treatment (Margesin and Schinner, 1997).

The five microorganisms used in this study differed in their ability to degrade aromatic hydrocarbons. Some of them, such as Pseudomonas strain W, could degrade all investigated hydrocarbon compounds, but the maximum degradation of aromatic hydrocarbons was shown by Pseudomonas strain L. Catechol and aniline best supported bacterial growth.

Whyte, et al., (1997) conducted similar experiments, studying biodegradation of naphthalene by bacteria isolated from oilcontaminated soils.

Toledo et al., (2006) studied bacterial strains isolated from waste crude oil and their capacity for growth with naphthalene, phenanthrene, fluoranthene and pyrine as sole carbon sources. Our study differs from these, however, in that we studied growth rate of bacteria only in the presence of aromatic hydrocarbons.

\section{Microbial degradation of xenobiotic compounds}

Xenobiotics are organic in nature and many of the xenobiotic compounds released into the environment and accumulate because they are only degraded very slowly and in some cases so slowly as to render them effectively permanent. The degradation of xenobiotic compounds are depends upon microbial activity. Some example includes degradation of parathion. 
It should be examine the degradation pathway of xenobiotic compound when single substrate is available there. In absence of oxygen there should be an alternative electron accepter nitrate, sulphate, selenate, carbonate etc. There are no microbes or group of microbes that degrade all compounds. So there should be a group of organism, metabolically versatile that is applicable for the degradation of large no of compound.

Microorganisms play a major role in degradation of xenobiotics. They transform toxic contaminants in to non-hazardous or less hazardous substances. Most of the microorganisms, particularly bacteria are known for detoxifying abilities. They mineralize, transform or immobilize the pollutants. Examples of aerobic and anaerobic xenobiotics degradative bacteria are Pseudomonas, Gordonia, Bacillus, Moraxella, Micrococcus, Escherichia, Sphingobium, Pandoraea, Rhodococcus, and anaerobic xenobiotics degradative bacteria are Pelatomaculum, Desulphovibrio, Methanospirillum, Methanosaeta desulfotomaculum, Syntrophobacter, Syntrophus.

\section{Biodegradation pathway of xenobiotics compound}

Microorganisms apply two modes of action for degradation of xenobiotics compound: (a) aerobic biodegradation and (b) anaerobic biodegradation.

\section{Aerobic biodegradation pathway}

Some of the xenobiotics like petroleum hydrocarbons, chlorinated aliphatics, benzene, toluene, phenol, naphthalene, fluorine, pyrene, chloroanilines, pentachlorophenol and dichlorobenzenes are rapidly and potentially degraded by the aerobic degradation process. Many bacterial consortia capable to grow on these chemicals they are producing enzymes which degrade toxic compounds to non-toxic compounds.

Xenobiotic compound + O2--------------CO2 $+\mathrm{H} 2 \mathrm{O}+$ biomass + residue(s) (Shimao, 2001).

The process of conversion of biodegradable materials to gases like carbon dioxide, methane, and nitrogen compounds is called mineralization. Mineralization process is completed, when all the biodegradable biomass is consumed and all the carbon is converted into carbon dioxide (Kyrikou and Briassoulis, 2007).

\section{Anaerobic biodegradation}

Some pollutants are not mineralized by an aerobic degradation process; they are polychlorinated biphenyls (PCBs), chlorinated dioxins and some pesticides like DDT. It is necessary to overcome the high persistence of halogenated xenobiotics from the biosphere, for achieving these, reductive attacks by anaerobic bacteria is

Xenobiotic compound

$\mathrm{CO} 2+\mathrm{CH} 4+\mathrm{H} 2 \mathrm{O}+$ biomass + residue $(\mathrm{s})$ (Jayasekara et al., 2005).

The four processes are briefly discussed next. Particular attention is dedicated to pesticides, which stand out as one of the major developments of the twentieth century. During the last years, however, concern has arisen as to the extent that their presence in the environment poses a threat to wildlife and humankind. Certainly, pesticides have improved longevity and the quality of life, chiefly in the area of public health. The use of pesticides also constitutes an important aspect of modern agriculture, for without chemicals to control various pests like insects, weeds, plant diseases, worms, and rodents, our food supply would decrease and prices would increase. 


\section{GMO as a tool of soil pollution reduction}

Recombinant DNA techniques have been studied intensively to improve the degradation of hazardous waste under laboratory condition. The genetically engineered microorganisms have higher degradative capacity and have been demonstrated successfully for the degradation of various pollutants under defined conditions. Genetic modification technology has resulted often in a wide variety of current and potential applications for use in the process of bioremediation. Bioremediation explores gene diversity and metabolic versatility of microorganisms (Fulekar, 2009).

The use of genetically modified (GM) bacteria represents a research frontier with broad implications. The potential benefits of using genetically modified bacteria are significant. But the need for GM bacteria may be questionable for many cases, considering that indigenous species often perform adequately but we do not tap the full potential of wild species due to our limited understanding of various phytoremediation mechanisms, including the regulation of enzyme systems that degrade pollutants.

Moreover, the efficiency of microorganisms engineered with organophosphate hydrolyses (the most involved degrading enzyme) encoding gene opd (organophosphatedegrading) genes was tested against a wide range of organophosphorus compounds in liquid cultures and soil systems (Singh and Walker, 2006).

\section{References}

Act No. 220/2004 (2004): On the Protection and Use of Agricultural Land. National Council of Slovak Republic, Bratislava.

Ahemad, M. 2014. Remediation of metalliferous soils through the heavy metal resistant plant growth promoting bacteria: Paradigms and prospects. Arab. J. Chem., doi:10.

Alquati C, Papacchini M, Riccardi, Spicaglia C, Bestetti G 2005. Diversity of naphthalene-degrading bacteria from a petroleum contaminated soil. Ann Microbial 55: 237-242.

Baduru Lakshman Kumar and D. V. R. Sai Gopal, 2015. Effective role of indigenous microorganisms for sustainable environment biotech. Dec; 5(6): 867-876.

Barra Caracciolo, A., P. Grenni, C. Cupo, and S. Rossetti, 2005b. In situ analysis of native microbial communities in complex samples with high particulate loads. FEMS Microbiology Letters253: 55-8.

Basta, N. T., J. A. Ryan, and R. L. Chaney 2005. Trace element chemistry in residual-treated soil: key concepts and metal bioavailability, Journal of Environmental Quality, vol. 34, no. 1, pp. 49-63.

Bjuhr, J., 2007. Trace Metals in Soils Irrigated with Waste Water in a Periurban Area Downstream Hanoi City, Vietnam, Seminar Paper, Institutionen för markvetenskap, Sveriges lantbruksuniversitet (SLU), Uppsala, Sweden.

Bould, H.L., 1994. DDT residues in the environment- a review with a New Zealand perspective. New Zealand Journal of Agricultural Research38, 257-277.

Burgess, L.C. 2013. Organic pollutants in soil. In: Brevik, E.C. and Burgess, L.C. eds 2013. Soils and Human Health. Boca Raton: CRCPress. pp. 83-102.

Commission Proposal COM (2006) for a Directive of the European Parliament and of the Council establishing a framework for the protection of soil and amending Directive 2004/35/EC. 
D'Amore, J.J., S. R. Al-Abed, K. G. Scheckel, and J. A. Ryan 2005. Methods for speciation of metals in soils: a review, Journal of Environmental Quality, vol. 34, no. 5, pp. 1707-1745.

DeVolder, P. S., S. L. Brown, D. Hesterberg, and K. Pandya 2003. Metal bioavailability and speciation in a wetland tailings repository amended with biosolids compost, wood ash, and sulfate, Journal of Environmental Quality, vol. 32, no. 3, pp. 851-864.

FAO, (March, 2009). ResourceSTATFertilizer. Food and Agriculture Organization of the United Nations.

Fulekar MH. 2009. Bioremediation of fenvalerate by Pseudomonas aeruginosa in a scale up bioreactor. Romanian Biotechnological Letters, 14(6): 49004905

George, Rebecca; Joy, Varsha; S, Aiswarya; Jacob, Priya A 2016. "Treatment Methods for Contaminated Soils Translating Science into Practice". International Journal of Education and Applied Research. Retrieved February 19.

Gullan, P.J. and Cranston, P.S. 2010. The Insects: An Outline of Entomology, 4th Edition. Blackwell Publishing UK: 584 $\mathrm{pp}$.

Hoff, R. Z., 1983. Bioremediation: an overview of its development and use for oil spill cleanup. Marine Pollution Bulletin, vol. 26, no. 9, pp. 476-481.

Jayasekara, R., Harding, I., Bowater, I. and Lonergan, G. 2005. Biodegradability of selected range of polymers and polymer blends and standard methods for assessment of biodegradation. Journal of Polymers and Environment; 13(3): 231-250.

Jones L. H. P., and S. C. Jarvis, 2002. The fate of heavy metals. The Chemistry of Soil Processes, D. J. Green and M. H. B. Hayes, Eds., p. 593, John Wiley \&
Sons, New York, NY, USA,. EPA's National Service Center for Environmental Publications.

Kabata-Pendias, A., and H. Pendias 2001. Trace Metals in Soils and Plants, CRC Press, Boca Raton, Fla, USA, 2nd edition.

Keller, C., S. P. McGrath, and S. J. Dunham 2002. Trace metal leaching through a soil-grassland system after sewage sludge application, Journal of Environmental Quality, vol. 31, no. 5, pp. 1550-1560.

Kyrikou, J. and Briassoulis, D. 2007. Biodegradation of Agricultural Plastic Films: A Critical Review. Journal of Polymer and Environment; 15: 125150.

Lacatusu, R., M. Dumitru, I. Risnoveanu, C. Ciobanu, Mihaela Lungu 1999. Soil Pollution by Acid Rains and Heavy Metals in Zlatna Region, Romania International Soil Conservation Organization Meeting held May.

Lasat M.M., 2000. Phytoextraction of metals from contaminated soil: a review of plant/soil/metal interaction and assessment of pertinent agronomic issues. Journal of Hazardous Substances Research, vol. 2, pp. 1-25.

Leung, M., 2004. Bioremediation: techniques for cleaning up a mess. Journal of Biotechnology, vol. 2, pp. 18-22.

Liliana Gianfreda and Maria A. Rao 2008. Interactions between Xenobiotics and Microbial and Enzymatic Soil Activity, Critical Reviews in Environmental Science and Technology, 38:4, 269-310.

Margesin R, Schinner F 1997. Efficiency of indigenous and inoculated cold adapted soi microorganisms for biodegradation of diesel oil in Alpine soils. Appl Environ Microbiol 63: 2660-2664.

Mattigod S. V., and A. L. Page 1983. Assessment of metal pollution in soil. Applied Environmental Geochemistry, 
pp. 355-394, Academic Press, London, UK.

McLaren, R. G., L. M. Clucas, and M. D. Taylor 2005. Leaching of macronutrients and metals from undisturbed soils treated with metalspiked sewage sludge. 3. Distribution of residual metals. Australian Journal of Soil Research, vol. 43, no. 2, pp. 159170.

McLaren, R. G., L. M. Clucas, M. D. Taylor, and T. Hendry 2004. Leaching of macronutrients and metals from undisturbed soils treated with metalspiked sewage sludge. 2. Leaching of metals, Australian Journal of Soil Research, vol. 42, no. 4, pp. 459-471.

Nichols, W. J., 2001.The U.S. Environmental Protect Agency: National Oil and Hazardous Substances Pollution Contingency Plan, Subpart J Product Schedule (40 CFR 300.900). in Proceedings of the International Oil Spill Conference, pp. 1479-1483,

Pierzynski, G.M., J. T. Sims, and G. F. Vance 2000. Soils and Environmental Quality, CRC Press, London, UK, 2nd edition.

Reed, S. C., R. W. Crites, and E. J. Middlebrooks 1995. Natural Systems for Waste Management and Treatment, McGraw-Hill, New York, NY, USA, 2nd edition.

Risk Assessment Guidance for Superfund, Human Health Evaluation Manual, Office of Emergency and Remedial Response, U.S. Environmental Protection Agency, Washington D.C. 20450.

Scragg 2006. Environmental Biotechnology, Oxford University Press, Oxford, UK, 2nd edition.

Shen, L., Wania, F., Lei, Y.D., Teixeira, C., Muir, D.C., Bidleman, T.C., 2005. Atmospheric distribution and longrange transport behavior of organochlorine pesticides in North
America. Environmental Science and Technology 15, 409-420.

Shimao, M. 2001. Biodegradation of plastics. Current Opinion in Biotechnology; 12: 242-247.

Singh D, Fulekar MH. 2010. Biodegradation of petroleum hydrocarbons by Pseudomonas putida strain MHF 7109 isolated from cow dung microbial consortium. Clean Soil, Air, Water, 38(8): 781-786.

Singh SN, Tripathi RD 2007. Environmental bioremediation technologies, SpringerVerlag Berlin Heidelberg.

Singh, B. K., and Walker, 2006 A. Microbial degradation of organophosphorus compounds. FEMS Microbiol. Rev., 30, 428-471.

Smith, L.A., J. L. Means, A. Chen et al., 1995. Remedial Options for MetalsContaminated Sites, Lewis Publishers, Boca Raton, Fla, USA,

Sönmez, I., M. Kaplan and S. Sönmez 2007. An investigation of seasonal changes in nitrate contents of soils and irrigation waters in greenhouses located in antalya-demre region," Asian Journal of Chemistry, vol. 19:7 pp. 5639-5646.

Sumner, M. E. "Beneficial use of effluents, wastes, and biosolids 2000. Communications in Soil Science and Plant Analysis, vol. 31, no. 11-14, pp. 1701-1715.

Talley J 2005. Introduction of recalcitrant compounds. In W. Jaferey \& L. Talley (Eds. Bioremediation of recalcitrant compounds. Boca Raton: CRC.

Toledo FL, Calvo C, Rodelas B, GonzálezLópez J 2006. Selection and identification of bacteria isolated from waste crude oil with polycyclic aromatic hydrocarbons removal capacities. Syst Appl Microbiol 29: 244-252. 
Vidali, M., 2001. Bioremediation. An overview, Pure and Applied Chemistry, vol. 73, no. 7, pp. 1163-1172.

Wasi S, Jeelani G, Ahmad M 2008. Biochemical characterization of a multiple heavy metal, pesticides and phenol resistant Pseudomonas fluoresces strain. Chemosphere 71: 1348-1355.

Whyte LG, Bourbonnière L, Greer CW 1997. Biodegradation of petroleum hydrocarbons by psychrotrophic
Pseudomonas strains possessing both a Alkane (alk) and naphthalene (nah) catabolic pathways. Appl Environ Microbiol 63: 3719-3723.

Yan ez, L., Ortiz-Pe' rez, D., Batres, L.E., Borja-Aburto, L., D1'az-Barriga,F., $2002 . \quad$ Levels of dichlorodiphenyltrichloroethane and deltametrin in humans and environmental samples in malarious areas of Mexico. Environmental Research Section A 88, 174-181.

\section{How to cite this article:}

Narayan Prasad Verma, Dhannidevi, Bhisham Sinha and Anjulata Suman Patry. 2017. Role of Microorganisms for the Sustainable Use of Soil Pollution Abutment in Agriculture Lands. Int.J.Curr.Microbiol.App.Sci. 6(11): 335-350. doi: https://doi.org/10.20546/ijcmas.2017.611.038 